kom i obrazovanjem te politikom prema mladima. Zadnje poglavlje povezuje strategije rasta i socijalne reforme te doprinosi razumijevanju procesa transformacije rasta i socijalnih režima. Dakle, važno je istaknuti, socijalne reforme dio su vladinih gospodarskih strategija rasta. Specifične strategije rasta povezuju se sa specifičnim reformama socijalne države. Izazovi razvoja države socijalnih ulaganja s vidljivim povratima ostaje izazov za mnoge ovdje analizirane socijalne države. Ne postoji jedan mehanizam koji povezuje strategije rasta i socijalne reforme. Autori navode tri mehanizma: 1 . socijalni sustav djeluje kao input rasta; 2. postojeći socijalni sustav percipira se kao prepreka rastu, potrebne su reforme, rezanja troškova ili njegova transformacija za poticanje rasta i 3. rast se događa bez pozitivnih redistributivnih učinaka, socijalna država jača se kao kompenzatorski alat.

Pet analiziranih strategija rasta povezuje se s pet tipova reformi socijalne države: manufakturna izvoza strategija rasta i dualizacija socijalne države; strategija izvoza dinamičnih usluga i socijalna ulaganja; strategija vođena izravnim inozemnim ulaganjima te fiskalna i socijalna atraktivnost; strategija rasta utemeljena na financijalizaciji i komodifikacija socijalne politike; strategija rasta utemeljena na javno financiranoj domaćoj potražnji i socijalni protekcionizam.

Knjiga je kompleksno i vrijedno štivo, zahtijeva pomno studiozno čitanje i pruža nove uvide o povezanosti socijalnih reformi kao dijela politika strategija rasta. Izloženi rezultati istraživanja su poticajni i mogu se prenijeti u koncipiranjima i istraživanjima reformi socijalne države u Hrvatskoj. Knjiga se među OECD zemljama manje bavi temama koje su povezane uz tranzicijske zemlje na koje se odnosi strategija vođena izravnim inozemnim ulaganjima te fiskalna i socijalna atraktivnost. Primjerice, ne ističu se izazovi povezni s privatizacijom mirovinskog sustava u ovim zemljama, a što je trebao biti jedan od temelja gospo- darskoga rasta. Istraživanja su pokazala da strana ulaganja u ovim zemljama daju veće profite nego u zemljama zapada iz kojih dolaze. K tome, ne navode se podaci o seljenju kvalificirane radne snage iz ovih zemalja u razvijenije EU zemlje. To je bilo istaknuto i kao jasna kritika prilikom predstavljanja ove knjige na webinaru 29.3.2021. Više vidjeti na mrežnoj stranici: https://www. civica.eu/news-events/future-past-events/ growth-and-welfare-in-advanced-capitalist-economies/.

\section{Gojko Bežovan}

Studijski centar socijalnog rada

Pravni fakultet Sveučilišta u Zagrebu

doi: 10.3935/rsp.v28i3.1855

\section{SOCIJALNA POLITIKA HRVATSKE (II. izdanje)}

\section{Gojko Bežovan i sur.}

Zagreb: Pravni fakultet Sveučilišta u Zagrebu, 2019., 577 str.

Sveučilišni udžbenik Socijalna politika Hrvatske sadržajno i konceptualno nastavlja se na istoimeni udžbenik iz 2008. godine, čime svjedoči o kontinuitetu sustavnih istraživanja na Katedri socijalne politike na Pravnom fakultetu Sveučilišta u Zagrebu, čiji djelatnici aktivno prate i evaluiraju stare i nove socijalne rizike te nove programe i mjere socijalne politike. Sedam autora, uvaženih stručnjaka u različitim područjima socijalne politike, udžbeničkim stilom pisanja i analize kroz komparativni pristup približavaju čitateljima kompleksne teme socijalne politike, ukazujući pritom na teorijske $\mathrm{i}$ istraživačke aspekte ove teme. Nakon uvodnog poglavlja, koje nudi opći pregled socijalne politike Hrvatske, slijede 
poglavlja posvećena hrvatskoj socijalnoj politici u vremenu globalizacije i europeizacije, mirovinskom sustavu, zdravstvenoj politici, politici zapošljavanja i nezaposlenosti, socijalnoj pomoći i uslugama socijalne skrbi, obiteljskoj politici, stanovanju i stambenoj politici, obrazovanju te civilnom društvu i kombiniranoj socijalnoj politici. Slijedi sažeti prikaz tema po poglavljima.

U uvodnom poglavlju, osvrćući se na povijesni kontekst i novije trendove, Vlado Puljiz daje opći prikaz razvoja socijalne politike Hrvatske. Autor početke ove politike, kao javne djelatnosti, smješta u drugu polovicu 19. i prvu polovicu 20. stoljeća, kada je hrvatsko društvo pretežno seljačko, a socijalni problemi pretežno se rješavaju na razini primarne društvene grupe. Do većih pomaka na ovom području dolazi u socijalističkom razdoblju, kada socijalna politika postaje ključan instrument upravljanja društvenim odnosima. Unatoč postupnoj modernizaciji i širenju socijalnih prava, socijalni problemi se umnožavaju i produbljuju. Socijalna politika neovisne Hrvatske prolazi razvojne etape - od krizne, ratne politike, preko reformi glavnih socijalnih sustava, do prilagodbe pravnom nasljeđu EU-a, no autor zaključuje da ista ostaje opterećena brojnim problemima i izazovima.

U sljedećem poglavlju, Gojko Bežovan analizira utjecaj globalizacijskih i procesa europeizacije na socijalnu politiku (Hrvatske), ističući da se radi o procesima koji dovode do novih pojmova i koncepata u socijalnoj politici, odražavajući njezin promijenjeni sadržaj i usmjerenost. Smatra da su globalizacijski procesi na europskoj razini uzdrmali fiskalne kapacitete socijalnih država, a u Hrvatskoj, posredstvom međunarodnih organizacija, pokrenuli i usmjerili reforme u određenim područjima socijalne politike. U kontekstu europeizacije, autor zaključuje da zbog politiziranog i fragmentiranog sustava socijalne politike Hrvatska nije ostvarila puni potencijal u razdoblju pristupanja i tijekom članstva u EU, da državne institucije nemaju kapacitet recepcije programa, dokumenata i smjernica EU-a te da malobrojna akademska zajednica i organizacije civilnog društva, unatoč naporima, ne mogu samostalno riješiti rastuće socijalne probleme.

U svojem drugom poglavlju, Vlado $\mathrm{Pu}-$ ljiz bavi se temom mirovinskog sustava. Nakon osvrta na definiciju, značaj i funkcije ovog sustava, u prvom dijelu poglavlja analizira njegov razvoj od začetaka (u 19. stoljeću) do danas. Najviše pažnje u drugom dijelu poglavlja autor posvećuje mirovinskom sustavu od stjecanja hrvatske neovisnosti. Pritom analizira osnovne pokazatelje i probleme s kojima se, u pogledu organizacije i financiranja mirovinskog sustava, hrvatsko društvo suočava posljednjih desetljeća, a poseban naglasak stavlja na mirovinske reforme (1999., 2002. i 2018. godine), koje su stalno polje sukoba interesa različitih dionika. Autor zaključuje da budućnost hrvatskog mirovinskog sustava ovisi o gospodarskom rastu i zapošljavanju te ukazuje na nužnost razvijanja politika koje će kombinirati temeljnu socijalnu sigurnost i prevenciju siromaštva umirovljenika.

Siniša Zrinščak raspravlja o važnosti i kompleksnosti zdravstvene politike, koju drži neospornom za pojedinca i zajednicu jer pitanja zdravlja i bolesti imaju velike osobne i društvene posljedice. Nakon povijesnog pregleda razvoja, zakonskog okvira te konstatacije da je, unatoč nizu reformskih zahvata, on i dalje opterećen nizom proturječja i dilema, autor se osvrće na organizaciju, prava, financiranje, troškove $\mathrm{i}$ trendove $\mathrm{u}$ hrvatskom zdravstvenom sustavu. Potom iznosi podatke koji ukazuju da Hrvatska u ovom sektoru zaostaje za usporedivim zemljama, ističe nužnost prepoznavanja ulaganja u zdravstvo kao ulaganja u društvo u cjelini (a ne trošak) te zagovara javnu i stručnu raspravu o zdravstvu, a kao potencijalni reformski okvir vidi EU dokumente. 
Teo Matković piše o politici zapošljavanja i nezaposlenosti. U prvom dijelu poglavlja autor predstavlja koncept i odrednice te, prikazujući opću sliku kretanja nezaposlenosti u Hrvatskoj, uz poseban osvrt na nezaposlenost mladih te posljedice dugoročne nezaposlenosti. U drugom dijelu poglavlja bavi se socijalnim politikama usmjerenim na nezaposlene osobe te donosi kronološki pregled oblika, trajanja, troškova, dosega te učinaka aktivnih i pasivnih politika zapošljavanja. Zaključuje da ovaj sustav socijalne politike u Hrvatskoj nije posebno izdašan ni učinkovit. Autor poglavlje završava kratkim osvrtom na koncepte aktivacije i fleksigurnosti te prikazom europske dimenzije politike zapošljavanja i njezinog utjecaja na Hrvatsku.

Zoran Šućur autor je poglavlja o socijalnoj pomoći i uslugama socijalne skrbi. Nakon terminoloških određenja, autor se osvrće na četiri i pol desetljeća razvoja ovih sustava u razdoblju socijalizma, kada su osnovane prve profesionalne institucije i doneseni prvi socijalni zakoni. Zaključuje da su ovi sustavi u tom razdoblju, prije svega zbog političko-ideoloških razloga i dominacije ekonomske nad drugim sferama života, bili relativno zanemarivani. Autor zaključuje da, iako ovi sustavi danas pružaju osnovnu socijalnu sigurnost velikom broju hrvatskih građana, trendovi izdataka, usluga i ustanova upućuju na potrebu daljnjih reformi koje bi trebale doprinijeti njihovoj učinkovitosti.

Ivana Dobrotić bavi se obiteljskom politikom koja, unatoč tomu što u europskim zemljama postaje sve važnije područje državne intervencije u okviru koncepta socijalnog ulaganja, u Hrvatskoj često zauzima nisko mjesto na listi prioriteta donositelja odluka. Iako promjene u obiteljskim naknadama posljednjih godina prate i dugo priželjkivana ulaganja u širenje socijalne infrastrukture na ovom području, autorica smatra da i dalje izostaje sveobuhvatna socijalna politika koja bi se temeljila na do- kazima i stvarnim potrebama i problemima (budućih) roditelja. Također ukazuje na potrebu dugoročnog planiranja obiteljske politike koja će biti prioritet kako države, tako i drugih aktera (prije svega poslodavaca), i u koju će se ulagati značajnija sredstva, s ciljem povećanja prava, dobrobiti i kvalitete obiteljskog života.

U svojem drugom poglavlju, Gojko Bežovan analizira razvoj stambene politike kao dijela socijalne politike u Hrvatskoj. Autor argumentira da je sustav stambene politike iz socijalizma u velikoj mjeri odredio njezin razvoj u 1990-ima, kada se država povlači iz ovog područja, otvarajući prostor tržištu i špekulativnim interesima investitora, što je proizvelo dugoročne socijalne, gospodarske i demografske probleme. Zaključuje da bi se održivi model stambene politike trebao temeljiti na procjeni stambenih potreba te na izgradnji infrastrukture stambenih institucija, pri čemu bi, kao nositelji stambenih inovacija, važnu ulogu trebale imati neprofitne organizacije.

Poglavlje Zdenka Babića bavi se obrazovanjem, koje autor drži jednim od ključnih resursa ekonomske i socijalne dobrobiti pojedinaca te važnom determinantom njihove socijalne pozicije. Nakon povijesnog pregleda razvoja, strukture financiranja i institucionalnih promjena u sustavu obrazovanja, osvrće se na demografske, organizacijske i trendove komercijalizacije u osnovnom, srednjem i visokom obrazovanju, koji postaju sve izraženiji i ograničavajući čimbenik održivog razvoja Hrvatske. Autor zaključuje da je od presudne važnosti izgradnja kvalitetnog i svim socijalnim skupinama dostupnog sustava obrazovanja, koji istovremeno doprinosi konkurentnosti gospodarstva koje se temelji na znanju.

U posljednjem poglavlju, Gojko Bežovan analizira socijalnu politiku Hrvatske u kontekstu razvoja i uloge civilnog društva $i$ drugih dionika te razvoja kombinirane socijalne politike. Nakon definiranja osnov- 
nih pojmova i osvrta na povijesni razvoj civilnog društva, autor se detaljno bavi zakonskim, financijskim i policy okvirom djelovanja organizacija civilnog društva u Hrvatskoj. Zaključuje da se spomenuti okvir razvija dosta sporo, ali da danas organizacije civilnog društva, uslijed nemogućnosti države da odgovori na rastuće socijalne potrebe i rizike, proizvode socijalne inovacije i na dnevni red javnih rasprava stavljaju pitanja problema i prava različitih ugroženih skupina, čime doprinose održivim pozitivnim promjenama.

Referirajući se na mnoštvo povijesnih činjenica, statističkih podataka i novijih trendova iz različitih nacionalnih i međunarodnih izvora, autori poglavlja ovog udžbenika jasno uočavaju i objašnjavaju pojmove i probleme iz različitih područja socijalne politike Hrvatske, ističući, s visokim stupnjem socijalne osjetljivosti, njihovo značenje i važnost za ostvarivanje koncepata socijalne sigurnosti i socijalne kohezije. $\mathrm{Na}$ suvremen način analiziraju glavne socijalne rizike i temeljne pristupe institucija i aktera (socijalne) politike koji djeluju u području njihovog otklanjanja. Osnovni zaključak koji se nameće je da državne institucije nisu u stanju odgovoriti na rastuće socijalne izazove, kao ni pratiti razvoj novih ideja i koncepata (europske) socijalne politike, pa to ostaje zadatak akademske zajednice i civilnog društva.

Filip Trbojević Zagreb doi: 10.3935/rsp.v28i3.1853

\section{KORONA EKONOMIKA: PET JAHAČA APOKALIPSE}

\section{Velimir Šonje i Kristijan Kotarski}

Zagreb: Arhivanalitika d.o.o., 2020., 286 str.

Razmjerno brzo uslijed velikog broja zaraženih i preminulih uslijed pandemije COVID-19, Svjetska zdravstvena organizacija istaknula je kako se radi o izvanrednoj situaciji za javno zdravstvo od međunarodne važnosti, koja itekako ima utjecaj na društvo i socijalnu politiku. Mnogobrojne zemlje širom svijetu provode raznovrsne mjere kako bi se zaustavilo širenje virusa. To neminovno utječe na brojna ograničenja u velikom dijelu društva i ima vrlo nepovoljne gospodarske posljedice. Stanje je utoliko složenije i zahtjevnije što ustvari i godinu dana nakon izbijanja pandemije još uvijek nisu poznate sve odrednice njezinog nastanka te kako odrediti i provoditi mjere koje trebaju spasiti ljudske živote, ali i u što većoj mjeri očuvati gospodarstvo. O složenosti ovog odnosa izuzetno zanimljivu knjigu pripremili su Velimir Šonje i Kristijan Kotarski koju je 2020. objavila Arhivanalitika iz Zagreba. U cjelini, autori vrlo argumentirano i jasno iznose ekonomske i zdravstvene troškove zatvaranja (eng. lockdown) koji se također možda mogu mjeriti i gubitkom ljudskih života.

Šonje u uvodnim napomenama navodi kako usprkos redovitom statističkom praćenju broja zaraženih i preminulih još uvijek postoje prilično velike nepoznanice jer u smrtovnici obično treba navesti je li bolest COVID-19 uzrokovala ili se pretpostavlja da je uzrokovala ili doprinijela smrti. Stoga navedeni podaci po pojedinim zemljama lako mogu biti i podcijenjeni (jer mnoge starije osobe preminule su izvan bolničkog sustava) i precijenjeni (jer su mnogi stariji vjerojatno preminuli i od drugih 